\title{
BLACK LIVES MATTER: A THEOLOGICAL RESPONSE TO RACISM'S IMPACT ON THE BLACK BODY IN THE UNITED STATES
}

\author{
Christine M. Mitchell \\ Department of Social and Behavioral Sciences \\ Harvard T.H. Chan School of Public Health, Boston \\ cmitchell@mail.harvard.edu
}

\section{David R. Williams}

Department of African and African American Studies

Harvard University, Cambridge, MA

Department of Social and Behavioral Sciences

Harvard T.H. Chan School of Public Health, Boston

dwilliam@hsph.harvard.edu

\section{ABSTRACT}

After the killing of 18-year-old Michael Brown by police in Ferguson, Missouri in August 2014, there has been a renewed movement in the United States and across the world in support of black lives. The movement, under the guiding framework of Black Lives Matter, has resulted in a national conversation on police brutality and racism, and the violent effects these have on the black body. Using the framework of black theological thought on the body, this paper identifies the many ways that racism, as Ta-Nehisi Coates writes, "lands, with great violence, upon the body" across multiple domains and levels throughout history and across the life course. The paper closes with some initial recommendations for historically predominantly white churches to offer an anti-racist response to this violence, as informed by black theology.

Keywords: Black Lives Matter; black theology; racism; embodiment

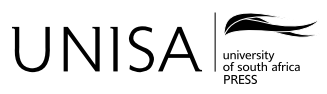


But all our phrasing-race relations, racial chasm, racial justice, racial profiling, white privilege, even white supremacy-serves to obscure that racism is a visceral experience, that it dislodges brains, blocks airways, rips muscle, extracts organs, cracks bones, breaks teeth. You must never look away from this. You must always remember that the sociology, the history, the economics, the graphs, the charts, the regressions all land, with great violence, upon the body. (Coates 2015, Between the World and Me, 10)

On 28 August 1955, 14-year-old Emmett Till was taken from his home, beaten, shot in the head, tied to a cotton gin fan, and thrown into a river. The two white men who brutally lynched him did so because Till allegedly flirted with a white woman four days ago. They were tried and an all-white jury deliberated for less than an hour before finding them not guilty. Till's mother, Mamie Till Bradley, made the decision to have an open casket for three days at the funeral home in order to reveal the horrific brutality of white supremacy and racist violence. Indeed, this decision awoke the U.S. to the violent realities of Jim Crow segregation ${ }^{1}$ and was one of the initial sparks of the Civil Rights Movement. Almost 60 years later, on 9 August 2014, 18-year-old Michael Brown was shot and killed by Darren Wilson, a police officer in Ferguson, Missouri. Brown's body was then left facedown and uncovered in the street for four and a half hours. This shooting and the uprising in Ferguson that followed brought forth a national movement for black lives and against police brutality. The movement is often identified under the Twitter hash tag \#BlackLivesMatter, which was co-created by Patrisse Cullors, Alicia Garza, and Opal Tometi. The hash tag was created a few years earlier after George Zimmerman, a neighbourhood watch volunteer in Sanford, Florida, was acquitted of the murder of 17-year-old Trayvon Martin as he walked home from the local convenience store. Garza writes that the hash tag was created as an ideological intervention, a call to action, and 'an affirmation of black folks' contributions to this society, our humanity, and our resilience in the face of deadly oppression" (Garza, n.d.). Now, along with being a political affirmation and ideology, Black Lives Matter represents a hash tag, a national organisation of local chapters, and a global movement.

Violence against black and brown bodies has deep and inextricable roots in the history of the United States. Frequently, it is these stories of brutal and public physical violence that capture the most media attention and therefore spark the deepest outrage among a broader population. However, it is important to note a few important points. First, the stories of Emmett Till, Michael Brown, Eric Garner, Sandra Bland, and other black people whose names make national headlines do not begin and end with their deaths, though that is often the only part of their stories told in the media. Each of these people had life stories and contexts beyond what is publicised and they should not be separated from those contexts. Second, it is important to note that there are thousands more black lives taken at the hands of racist violence than the stories that make it into

1 In 1838, the Southern States passed various laws of racial segregation, focused against the black sectors. By the turn of the century those laws were called the Jim Crow laws (www.historyinanhour. com/2013/09/23/the-jim-crow-laws-brief-summary/). 
the media. Third, we must recognise that violence is constantly landing on black and brown bodies, even when the cameras are not rolling and even when that harm is not immediately outwardly visible. This is the violence that is enacted between people and within structures and institutions that result in real mental and physical effects on people of colour. Countless studies identify racial inequities between blacks and whites across a number of different health outcomes, including rates of infant mortality, life expectancy, depressive symptoms, and cancer. These inequities cannot be traced to any biological or genetic difference across races (Yudell, Roberts, DeSalle and Tishkoff 2016) but instead have been shown to be attributable, in large part, to the multiple effects of the experience of racism. Using the framework of black theological thought on the body, this paper will identify the many ways that racism falls upon the black body across multiple domains and levels throughout history, and how black theology can inform churches' anti-racist response to this violence today.

We recognise that the issues addressed by this paper are not unique to the United States and that black theologians across the globe have written on the topic of the black body (Mofokeng 1983). Other societies, such as those in South Africa and Australia, also have a history of racial oppression and institutionalised racism (Elder 2003; Thompson 2001) and contemporary challenges with on-going racism (Paradies, Ben, Denson, Elias, Priest, Pieterse et al. 2015). However, due to space limitations, we have limited our discussion to the United States.

\section{THE CONCEPT OF THE BODY IN BLACK THEOLOGY}

The conceptualisation of the body in black theology takes different forms with varied focal points, depending on the scholar. This section will trace a high-level overview of the development of that concept from some of the major scholars in the field of black theology, including James Cone, Delores Williams, Anthony Pinn, and the understandings of the activists and scholars of today's Black Lives Matter movement. Ultimately, these scholars all specify in different ways that those who take seriously black liberation throughout the entirety of history must embrace the reality and lived experience of the body, and in particular, the black body.

James Cone approaches this goal via the rejection of Docetism, the Gnostic belief and Christian heresy that Christ's human body or historical existence was not real, but was illusory. Cone therefore focuses his recognition of the black body primarily as it relates to Christology. One of the starting points of Cone's Christology is that Jesus was historically black: he names this as an essential part of the Christian faith. If Christians are to believe that God is on the side of the oppressed and that God's will is to liberate the oppressed, then Jesus must be black. As Cone writes: "Christ's blackness is both literal and symbolic. His blackness is literal in the sense that he truly becomes One with the oppressed blacks, taking their suffering as his suffering and revealing that he is found in the history of our struggle, the story of our pain, and the rhythm of our bodies" (Cone 1975, 125). Cone notes that a Jesus who is not black negates the gospel message 
of "preach[ing] good news to the poor" or "set[ting] at liberty those who are oppressed" (Luke 4:18), and therefore cannot be reconcilable with the historical Jesus. Thus, it was a black man who was nailed to the cross on Calvary and took on the sins of humanity. Much of James Cone's discussion of the body hinges on the cross of Jesus and its parallels to the lynching trees upon which black Americans were hung and murdered throughout the nineteenth and twentieth centuries. Through the suffering and death of Christ on the cross, Cone writes: "God transformed lynched black bodies into the recrucified body of Christ. Every time a white mob lynched a black person, they lynched Jesus" (Cone 2011, 158). In Cone's The Cross and the Lynching Tree, the author is careful to clarify that finding salvation in the suffering and death of Jesus on the cross requires a "powerful religious imagination". Rather, he points out: "Salvation is broken spirits being healed, voiceless people speaking out, and black people empowered to love their own blackness" (Cone 2011, 158). However, he also marks the importance of being able to draw parallels between the cross and the social realities of black people in America, the importance of finding hope and empowerment in a God who never abandoned Jesus, who never abandons the black people being lynched in America, and who takes their suffering on as God's own. For instance, Cone uses the example of the prayer of Mamie Till Bradley at the funeral of her son, drawing a parallel between the crucifixion of Jesus and the lynching of her son: "Lord you gave your son to remedy a condition... but who knows, but what the death of my only son might bring an end to lynching" (Cone 2011, 67).

The final chapter in The Cross and the Lynching Tree addresses the particular stories and struggles of black women in the movement against lynching. Citing the examples and words of black women such as Ida B. Wells, Fannie Lou Hamer, Ella Baker, and Nellie Burroughs, Cone identifies the cross as a symbol of empowerment, rather than a symbol of redemptive suffering. For these women and others Cone recalls from his family and church: "The cross sustained them-not for suffering but in their resistance to it" (Cone 2011, 148). In other words, the cross of Jesus was a sign not meant to reify suffering, but a sign that God walked with these women through that suffering and would not abandon them. Indeed, womanist theologian Delores Williams offers a powerful critique of finding redemption or atonement in the suffering of Jesus on the cross. Williams sees little to no redemptive or positive value in "oppressed black women identifying with Christ through their common suffering wrought by crossbearing" (Williams 1993, 169). She challenges this in her 1993 Sisters in the Wilderness through an analysis of surrogacy: the surrogacy of Jesus to take on the sins of humanity and the surrogacy of black women in the antebellum era and today. Williams discusses three areas of coerced surrogacy placed upon black women in the antebellum South. The first was in the area of nurturance: black women slaves were "mammies"-taking on the role of the slave-owner's wife to take care of the children and keep the household running. The second was in the area of field labour: black women slaves were forced to take on the role of physical labour usually associated with men, such as tending to the crops or carrying logs. The third area of surrogacy Williams notes is in the area 
of sexuality: black women slaves were forced to take on the role of providing sexual pleasure to white male slave-owners, a role that white women usually filled according to the racist realities of the time. Post-slavery, Williams notes, many of these surrogate roles remained, though sometimes more voluntarily. Today, black women face the threat of what Williams refers to as "breeder women" or commercial surrogacy for pregnancies. Each of these types of surrogacy lands with violence on the bodies of black women. Given this history of exploitation, Williams writes: "It is therefore fitting and proper for black women to ask whether the image of a surrogate-God has salvific power for black women or whether this image supports and reinforces the exploitation that has accompanied their experience with surrogacy" (Williams 1993, 162). Rather than finding redemption or liberation in the cross, even insofar as Cone suggests finding liberation in a God that does not abandon the black body on the cross, Williams offers to black women that redemption rather comes 'through Jesus' ministerial vision of life and not through his death" (Williams 1993, 167). It is important to Williams that black women know that "God did not intend the defilement of their bodies as white men put them in the place of white women to provide sexual pleasure for white men during the slavocracy" (Williams 1993, 166). Similarly, "Jesus did not come to be a surrogate" (Williams 1993, 167). Rather, he came for life, providing an exemplary ministerial vision for right relationship, resistance, compassion, love, and healing.

Humanist theologian Anthony Pinn presents an entirely different view of the black body within the context of black theology, challenging traditional black and womanist theology for their Christian-centred focus. Rather than placing God or Christ at the centre of his theology, Pinn places black bodies at the centre. Pinn rightly notes that very little of black theology wrestles with the conception of the physical body, instead considering the body in a somewhat metaphorical manner. He writes: "Black theological thought related to issues of liberation and life meaning, when framed in terms of the body, tend toward the body only as abstraction, as symbol with little attention to the lived body" (Pinn 2010, 3). Pinn problematises this approach with his book Embodiment and the New Shape of Black Theological Thought, where he crafts a black theology that holds the body at its centre. He recognises that understanding the ways that racism and white supremacy are experienced physically by the material body, and to ignore this reality also ignores the materiality of liberation. Pinn's conception of the body, informed by Foucault, is one that takes into consideration both the biochemical realities of the body and the ways in which it is formed and understood by social discourse and power relationships. For Pinn, it is important that we recognise the body as both of these parts-the discursive and the material-because the two parts are inseparable. This understanding is critical to linking the ways that racist and white supremacist social power structures have a physical impact on the black body, as well as how one can work to address the roots of that physical impact. Pinn writes that "physicality is necessary in order to understand and work through oppressive circumstances and address the pain and suffering promoted by those circumstances. Power relations are not simply thought but are performed through the placement of real, fleshly bodies in time and space" 
(Pinn 2010, 9). In understanding and responding to pain and suffering, Pinn rejects the usefulness of theodicy as "theological throat clearing" (Pinn 2010, 149), giving preference instead to an "embodied response" (Pinn 2010, 150) that addresses not only the individual's experience but also the larger, structural, systemic issues that lead to the harm of the body.

Pinn's ideas-including his humanist framework, his centring of the black body, his call for an embodied response to violence against the body, and his attention to larger, structural issues-are ones that resonate in the writings of the activists and scholars who craft a theology of the current movement for black lives in the U.S.. Though some churches and clergy members have played a supportive role in the movement, many of the young activists on the ground are organising outside of any religious organisation. An Atlantic article notes: "Unlike their predecessors in the '60s and '70s-who included black liberation theologians such as James Cone-the current generation of young black activists is calling for a network of black institutions built outside the context of the strongest black institution there is: the church" (Green 2016). Though black people are among those most likely to identify with a formal religious affiliation, many young black activists are finding their church out in the streets, organising and protesting for racial justice. Rather than forming an abstract Christological understanding of the suffering and violence enacted at the hands of the state, many of these activists and scholars are embracing an atheistic framework that restores focus to the black body, the violence towards it enacted by structures of white supremacy, and the need for people to involve their physical bodies in the movement in street protests. Yet another example of this is given by Ta-Nehisi Coates, author of the 2015 best-seller Between the World and $M e$, who centres his book, written in the form of a letter to his 15 -year-old son, on the experience of living in a black body in America. One of the most oft-quoted lines in the book is: "In America, it is traditional to destroy the black body-it is heritage" (Coates $2015,103)$. Coates, an avowed atheist, rejects any sort of theodicy to make meaning of this destruction:

You must resist the common urge toward the comforting narrative of divine law, toward fairy tales that imply some irrepressible justice. The enslaved were not bricks in your road, and their lives were not chapters in your redemptive history. They were people turned to fuel for the American machine. Enslavement was not destined to end, and it is wrong to claim our present circumstance-no matter how improved-as the redemption for the lives of people who never asked for the posthumous, untouchable glory of dying for their children. (Coates 2015, 70)

Marquis Bey, in a recent issue of the Journal of Feminist Scholarship, proposes an atheistic black radical feminism that emphasises an acknowledgement of the body and the embodied lived experience, particularly in the current Black Lives Matter movement. Based strongly in Pinn's framework of embodiment, Bey writes: "Black lives can only matter if black bodies matter first" (Bey 2015). Recognising the importance of remembering all of the black lives which have been taken by law enforcement, Bey challenges the deification and "pseudocrucifixion" of people like Michael Brown, 
writing that "if these victims are not kept in close relation with their lived bodily experiences, which exist in a continual chain of other lived black experiences that have succumbed to similar fates, we run the risk of dissolving the body that was of utmost importance to their experiences" (Bey 2015). To disembody these victims by making them into Christ-like martyrs, we remove them from their historical and contemporary contexts, which play a role not only in understanding their bodies but in finding ways to address the structures that perpetrate the violence against those bodies. Indeed, to erase the lived bodily experience of someone like Michael Brown not only erases the lived black experiences of those that came before him, but also erases the lived black experiences Brown himself had in his 18 years-day-to-day experiences that quite likely also had a violent impact on his body.

\section{THE PHYSICAL EMBODIMENT OF RACISM IN THE UNITED STATES}

Racism is a form of discrimination based on racial identity that functions on multiple levels across various domains throughout history. The definition of the term necessarily must include the power relationship between the dominant (in this case, white) group and historically marginalised groups. One of the authors of this paper, David Williams, has previously defined this term as "an organized system premised on the categorization and ranking of social groups into races and devalues, disempowers and differentially allocates desirable societal opportunities and resources to racial groups regarded as inferior" (Williams and Mohammed 2013). The four levels across which racism functions are structural, institutional, interpersonal, and internalised racism. Structural racism involves those broad policies and societal influences formed throughout history that privilege the dominant group while disadvantaging and often causing significant harm to people of colour. This level of racism includes the larger social systems-such as education, health care, housing, and criminal justice-which are entrenched in racist ideology and praxis. Occasionally defined together with structural racism, institutional racism is racism that functions within the workings of particular institutions, such as schools, hospitals, or prisons. Interpersonal racism is perhaps the form of racism that is most widely recognised, as the either explicit or implicit racism from a white person directed towards a person of colour. Finally, internalised racism is the acceptance, whether conscious or unconscious, of society's negative stereotypes of one's own racial group (Krieger 2014). It is critical to keep in mind that each of these levels of racism operate within the particular social and historical context of the United States, beginning with the genocide of indigenous peoples and the brutalisation, enslavement and dehumanisation of black and brown bodies at the foundation of the country, and carrying into Jim Crow era segregation through 1965 and its vestiges-which continue to this day. Furthermore, the effects across these levels of racism, as Coates writes: "[L] and, with great violence, upon the body" (Coates 2015, 10). 
One reason it is so important to embrace a black theology that acknowledges the physicality of the black body, the social structures that shape the body, and the entirety of lived experience, is because racism has a lifelong physical and mental impact on the black body. We know that in race-conscious societies, the non-dominant racial groups have worse health outcomes than the dominant racial group. For instance, in the U.S., for every 1000 live births, non-Hispanic whites lose 5.1 infants to infant mortality, while non-Hispanic blacks have a much higher rate of infant mortality with 11.3 deaths out of every 1000 live births (Kaiser Family Foundation 2013). Life expectancy for black Americans also lagged by 8.3 years in 1950, and while the gap has been cut in half to about 4.1 years in 2010, blacks are still dying several years earlier than whites in the U.S. (NCHS 2013). If we froze the life expectancy of whites and had the life expectancy of blacks increase at the average rate at which life expectancy has increased in the last decade, it would take about 30 years to close the four-year gap. The phenomenon of biological weathering, as explained by Geronimus, Hicken, Pearson, Seashols, Brown and Cruz (2010), is found in evidence of more physiological wear and tear and more rapid biological aging of blacks in the U.S. than whites (Geronimus et al. 2010). Evidence of this wear and tear is found by measuring "allostatic load", a set of biomarkers that capture the physiological burden of stress and adaptation to that stress on the body. Weathering is driven by the cumulative impact of repeated exposures to psychological, social, physical and chemical stressors throughout the life course in one's residential, occupational and other environments, and adapting to or coping with these stressors. Given the racist realities of the U.S., blacks have greater frequency, clustering, and likely intensity and duration of stressors than whites. Following this hypothesis, a study by Geronimus Hicken, Keene and Bound (2006) revealed that blacks had higher scores on the allostatic load measure and greater probability of high scores at any age than whites. The findings also showed that blacks had earlier deterioration of health than whites, with the mean score for blacks being comparable to that of whites who were 10 years older, across each age group. Controlling for poverty status did not explain racial differences (Geronimus et al. 2006). Weathering was also evident in a study of telomere length for black and white women. Telomeres are sequences of DNA at the end of a chromosome and are an indicator of biological aging. The study found that black women had shorter telomere length than white women of the same chronological age that was equivalent to accelerated biological aging of 7.5 years (Geronimus et al. 2010). These studies all show how chronic stressors across the life course-most critically here, the stressors brought about by racism-can become literally embodied.

Beginning with structural racism and working inwards to internalised racism, there are multiple studies that show the negative health impact of each level of racism on the black body. Structural racism operates across many domains, including but not limited to housing, education, healthcare, criminal justice, and the labour market. One domain in which structural racism operates is in residential segregation. As black and brown populations have been geographically isolated and marginalised, health outcomes and life opportunities are also adversely affected. Widely understood as one of the central 
determinants of racial disparities in the U.S., racial segregation can have a number of effects on health. Segregation can limit one's socioeconomic mobility by determining access to quality education and employment opportunities. By limiting educational opportunities due to poor funding of public schools in communities with high concentrations of poverty, segregation leads to higher high school drop-out rates, lower average test scores, less access to quality teachers or academic counselling, higher levels of teen pregnancy, and lower probability of enrolment in college (Williams and Collins 2001). Employment opportunities are limited by the fact that corporations may base their location decisions on the demographic composition of the area and negative stereotypes associated with that composition. Residential segregation can also create pathogenic environments for blacks. One study of the 171 largest cities in the U.S. revealed that "the worst urban context in which whites reside is considerably better than the average context of black communities" (Sampson and Wilson 1995). Neighbourhood quality and housing quality decline as political leaders may decide to disinvest in poor black communities. Regarding health behaviours, segregation may lead to decreased access to recreational facilities conducive to physical exercise, as well as to decreased access to other services supportive of good health, such as grocery stores. Finally, segregation is correlated with lower access to quality healthcare and reduced access to pharmacies with necessary medications in stock (Williams and Collins 2001).

We also see the violence of structural racism on the black body in the domain of criminal justice. At the time of writing, 795 people have been killed by the police in the U.S. in 2016, with blacks at a rate of 4.8 per million, second only to Native Americans at a rate of 5.49 per million (The Guardian: The Counted 2016). Stop-and-frisk policing policies are usually disproportionately enacted on black and brown populations and early surveys show that young men who were stopped more frequently by police and who reported higher levels of police intrusion (as calculated using measures of how often and where the men had been stopped and measures of police conduct during the encounter, including whether they were asked for identification, whether they were searched, whether the officer used harsh or racist language, and whether the officer threatened the men or used physical force) also reported higher levels of anxiety. Similarly, men with higher levels of lifetime stops and with higher reported levels of intrusion also reported higher levels of trauma (Geller, Fagan, Tyler and Link 2014). This violence carries into incarceration rates, with nearly one in three black men between the ages of 18 and 28 being in prison, jail, or on parole. Nearly one-half of the entire population of people in prisons (over two million people in total) is black. The U.S. is the only industrialised country in the West that still has a legal death penalty, one that is often reserved for people of colour and which Cone refers to as "legal lynching" (Cone 2011, 163).

Institutional racism, which operates within and between various institutions, also appears across multiple domains. One example is differential medical treatment provided within hospitals to black patients in comparison to white patients. A 2003 Institute of Medicine report entitled "Unequal Treatment" documents that across virtually all medical procedures in the United States, blacks and other minorities receive poorer 
quality medical care and less intensive treatment compared to whites (Smedley, Stith and Nelson 2003). A recent study published in PLOS ONE provides an example of this phenomenon. It shows that non-Hispanic blacks were significantly less likely to receive an opioid prescription for pain at discharge during ED visits for non-definitive conditions such as back pain and abdominal pain compared to non-Hispanic whites after adjusting for other covariates (Singhal, Tien, and Hsia 2016). This difference in treatment is likely driven by negative stereotypes and implicit bias of physicians identifying non-Hispanic black patients as potential "drug-seekers", although another recent study found that rates of opioid addiction and abuse among Hispanics and non-Hispanic blacks were lower than among non-Hispanic whites (Han, Compton, Jones and Cai 2015).

In education, rates of acceptance and retention of black students at medical schools are actually in decline. In 2014, there were 27 fewer black males in the first year of medical school than there had been 36 years earlier, in 1978. There is slight improvement in the medical force as a whole, with 2.9 per cent of all practising physicians in the U.S. being black in the mid-1960s, while in 2012, 3.8 per cent of all practising physicians were black (AAMC 2015; Deville, Hwang, Burgos, Chapman, Both and Thomas 2015). Unfortunately, there are still a disproportionately low number of black medical students and physicians represented in the field, which can also lead to diminished health outcomes among the black population.

One instrument that captures a measure of interpersonal racism is the "Everyday Discrimination Scale", which captures the frequency of a number of questions about interacting with others and which concludes with the question: "What do you think was the main reason for these experiences?" The scale asks how often the respondent experienced each item in their day-to-day life, including items such as: "You are treated with less respect than other people"; "People act as if they are afraid of you"; and "You are threatened or harassed" (Williams, Yu, Jackson and Anderson 1997). The impact of these experiences-whether the respondent attributes them to race, ethnicity, gender, sex, sexuality, religion, ability status, or other identity markers-accumulates in the physical body and results in a number of negatively impacted health outcomes. In a series of studies, epidemiologist Tené Lewis and colleagues have shown that everyday discrimination, often specifically as identified by African-American populations, is adversely related with a number of health outcomes, including: coronary artery calcification, C-reactive protein, blood pressure, lower birth weight, cognitive impairment, poor sleep, mortality, and visceral fat (Lewis, Courtney, Cogburn and Williams 2015).

Finally, internalised racism, as one takes on the negative stereotypes that society places on the black body, also has a significant health impact. The Nadanolitization scale, one measure of internalised racism, captures the level of discomfort of blacks towards other blacks as well as the level of endorsement of racist stereotypes of blacks, and studies show that one in three black people rank highly on this scale (Taylor and Grundy 1996). This high score was correlated with higher levels of alcohol consumption, higher levels of psychological distress, and higher rates of depressive symptoms (Taylor and Grundy 1996). Internalised racism can also result in the phenomena of: i) imposter 
syndrome-where one begins to question one's own abilities, merit, or success (Clance and Imes 1978); and ii) stereotype threat-where one behaves a certain way out of anxiety or fear of confirming a negative stereotype of one's own identity group (Steele 1995). Both of these phenomena can lead to increased levels of anxiety and diminished academic and occupational performance (Osborne 2007), which does harm not only to one's mental health but also to one's physical health.

These studies show that racism does both daily harm to the black body and overt, brutal, public, and often fatal harm that makes national news headlines. While it is critical to recognise, name, and condemn these publicised instances of racism, it should not take overt and brutal instances of racism to awaken people to the reality of white supremacy in the United States. This is why Pinn and other theologians have suggested that a theology that takes seriously black liberation must centre the material black body. More than a metaphorical abstraction, the black body carries the physicality of lived experiences. As Pinn notes, these are embodied experiences that require embodied responses. Indeed, in the public health literature, social epidemiologist Nancy Krieger also offers the concept of embodiment as central, defining the term as "a concept referring to how we literally incorporate, biologically, the material and social world in which we live, from in utero to death; a corollary is that no aspect of our biology can be understood in the absence of knowledge of history and individual and societal ways of living" (Krieger 2005). Thus, knowing that experiences of racism happen on multiple levels across a variety of domains throughout history, that such experiences do physical and material harm to the black body, and that black theologians have created a framework by which we understand and contextualise that body, the next step is to call religious communities and organisations into action to respond to these experiences.

\section{AN INTERRACIAL RELIGIOUS RESPONSE INFORMED BY BLACK THEOLOGY}

What does this knowledge mean for American churches in the era of today's Black Lives Matter movement? What spiritual and moral obligation do religious communities have in responding to the violence constantly perpetrated against the black body? Certainly institutional religion has to answer for its own role in perpetuating racism, from religious and scriptural justifications of slavery and Jim Crow segregation, to overt comments like this one by a Catholic priest quoted in the 1903 book The Miserable Condition of Black Catholics in America: "One wastes time and money in ministering to blacks... What reason can there be that you are so solicitous for the Negro?" (Unsworth 1997). Today, people who endorse an extrinsic religiosity that is utilitarian, rules-oriented, and legalistic, have higher associations with racial prejudice than those that endorse an intrinsic religiosity that is personally meaningful and integrated into one's worldview (Shreve-Neiger and Edelstein 2004). Those whose religion teaches a more rigid, closeminded worldview were also predictive of higher levels of prejudice (Hall, Matz and 
Wood 2010), though this prejudice is antithetical to the scriptural message of justice, compassion, empathy, and human dignity that many of the world's religions promulgate.

In the civil rights era, while many religious leaders sat on the side-lines, other religious leaders and religious organisations played a central role. Many civil rights leaders and activists emerged because of motivation by their religious values of justice, equality, and the affirmation of human life. In 1957, Martin Luther King, Jr., himself an American Baptist minister, gathered over 100 black religious leaders into an organisation named the Southern Christian Leadership Conference, created to harness the organising power and moral conscience of the black church for the Civil Rights Movement. Though black-led, white clergy also took on a role in spreading the message of the movement among their congregations. Analysing the role of clergy for civil rights in Tuscaloosa, Alabama, sociologist Nancy Ammerman writes: "White clergy often provided the only link between the movement and the white community" (Ammerman 1980). Clergy and religious leaders were on the front lines on the march for voting rights from Selma to Montgomery, Alabama, even resulting in the attack and murder of James Reeb, a white Unitarian Universalist minister from Boston.

In the current Black Lives Matter movement, a number of churches have begun hanging Black Lives Matter banners above their entryways. Some have begun hosting racial justice workshops or trainings. Some ministers have preached on police violence and racism and the church's obligation to address these issues. A few clergy have become prominent activists at protests and rallies, putting their bodies on the line and getting arrested for the sake of the movement. However, gathering support from the highest levels of leadership of religious institutions has been slow and difficult. For example, in the Catholic Church in the U.S., "fewer than 5 of the nation's 273 active Catholic cardinals and bishops have released statements or penned pastoral letters in response to the national outcry over the escalating and disproportionate rates of police and vigilante violence against black people" and "no active U.S. cardinal or bishop to date has dared to endorse, let alone proclaim publicly, Black Lives Matter" (Williams 2015). The United States Catholic Conference of Bishops did release a statement on "race relations" after their spring General Assembly in 2015, which acknowledged the enduring reality of racism in society and called for peace and reconciliation, but still have not endorsed the affirmation that Black Lives Matter (Cohen 2015). In another denomination, the United Methodist Church had formed a General Commission on Religion and Race in 1968 to address civil rights issues, and remains active today. However, about 150 United Methodists, unsatisfied with the lack of public response from the church to the Black Lives Matter movement, organised a demonstration in the middle of a plenary session of the 2016 General Conference. Pamela Lightsey, a black lesbian pastor, an associate dean at Boston University School of Theology, and co-organiser of the march, said in an article covering the demonstration: "We are upset about the lack of voice The United Methodist Church has given against police force (toward) black and brown bodies across the U.S.... which says they do not intend to put the power of this huge denomination against this" (Brodie 2016). Similarly, at a General 
Session of the General Assembly for the Unitarian Universalist Association (UUA) in 2015, a Youth Caucus put forward an Action of Immediate Witness proposal for the UUA to publicly support the Black Lives Matter movement. After a long, heated, and convoluted debate, the Action passed with near unanimity, but the process was arduous and hurtful enough that the Board of Trustees of the UUA later posted a statement in apology (McArdle 2015). The work in support of Black Lives Matter continued into the 2016 UU General Assembly.

Some of the resistance of the leadership of these denominations to get involved with the Black Lives Matter movement may arise from the demographic makeup of the churches and the differential understanding across people of different races of the realities of racism in the United States. A recent survey by the Public Religion Research Institute (PRRI) created a Racial Inequity Index (RII) with the intention of assessing respondents' view of whether systemic discrimination continues to drive racial inequities today. A lower score on the RII indicates that the respondent believes that racial minorities have equal opportunities to whites. The survey revealed that about 63 per cent of white evangelical Protestants, 61 per cent of white mainline Protestants, and 52 per cent of all Catholics have low scores on the RII, while about 32 per cent of religiously unaffiliated people and 17 per cent of black Protestants have low scores (Cooper, Cox, Lienesch and Jones 2015). These results clearly reveal the racial differences across and within Christian religions as to understanding racism as a contemporary problem. Indeed, in the denominations described in the previous paragraph, American Catholics are about 59 per cent white and three per cent black (Lipka 2015); United Methodists are about 90 per cent white and six per cent black (UMC General Council on Finance and Administration 2014); and Unitarian Universalists are about 78 per cent white and five per cent black (Pew Research Center 2015), with the remaining people identifying with other races/ethnicities. Reverend Osagyefo Sekou, a Baptist pastor from St. Louis, Missouri, suggests that an alternative reason for resistance from churches might be that the Black Lives Matter movement challenges the church's traditional sensibility:

I think a church has a role to play, but this idea of the Church, with a big C, I think is obsolete. The young people in the street disturb our religious respectability and sensibility. Queer woman, single moms, pants sagging, tattoos-it disrupts the very character that the church presents to the world. I'm not terribly hopeful for the church. I think queer, black, poor women are the church's salvation. (Van Gelder 2015)

How can religious leaders step out of their traditional presentation and truly engage in a decentralised movement led by queer black poor women?

In Baltimore, the site of a 2015 uprising after a 25 -year-old black man, named Freddie Gray, died from spinal injuries in police custody, organiser Brion Gill said in an interview with The Atlantic: "I don't think that people give enough credit to the church or the church's involvement... [but] the idea that it's not abundantly clear how many churches are involved in this work speaks to the lack thereof' (Green 2016). To be certain, some churches continue to play a vital role in the movement for black lives. But 
this involvement needs to extend more visibly to churches nationwide. The principles put forward by black theologians challenge churches to do better, to be more present, more vocal, and more active in the movement for black liberation. Framed by black theology, what does greater ecclesial involvement look like? First, predominantly white churches need to do a better job at creating interracial congregations. Often, churches and other institutional communities refer to the value of "integration" or of "diversity". These terms are problematic and do not get to the root of black liberation. James Deotis Roberts, another black theologian, writes: "Integration is a goal set by whites and is still based on the superordination-subordination principle of whites under whom they must live and serve" (Roberts 1971, 95). Indeed, the Cambridge Dictionary defines the word "integrate" as "to mix with and join society or a group of people, often changing to suit their way of life, habits, and customs" (Cambridge Dictionary 2016). Expecting black people to change themselves, their behaviours, their habits, or their customs in order to fit into a predominantly white religious space does not truly work for racial justice and equity. The goal of "diversity" carries with it similar problems in that it centres the increased presence of people from non-dominant groups within an already existing white structure, rather than reshaping that structure for a truly equitable distribution of power and responsibility. Deotis Roberts recommends instead that relationships between black people and white people should be "interracial"-allowing for a two-way interaction across races, without one being superior. Rather than promoting assimilation or colour-blindness, an interracial church recognises and celebrates the different lived experiences, customs, and habits of each member. As Deotis Roberts writes: "[I]t enables blacks to appreciate their own heritage to the extent that they consider it a worthy commodity to be shared with others" (Roberts 1971, 95).

Secondly, predominantly white churches eager to support the Black Lives Matter movement need to consider their adherence to maintaining the status quo, which is often historically grounded in an ethic of white superiority. In the case of black liberation, the oppressor cannot dictate the grounds on which the oppressed get free. This problem often arises in the context of evaluating the tactics of the movement. Many Christian churches focus on an ethic of love and forgiveness, pointing to the example of Jesus in the gospels. James Cone problematises this ethic in his God of the Oppressed, identifying this as a viewpoint of "white defenders of the status quo" (Cone 1975, 204). He writes: "It is interesting that many white scholars are sceptical about the historical validity of practically everything that the Gospels record about Jesus' ministry except his political involvement. They are sure that he preached love, which they invariably interpret to mean an acceptance of the political status quo. His gospel, they contend, was spiritual or eschatological but had nothing to do with political, revolutionary struggle" (Cone 1975, 204). Cone challenges this assumption and calls for a more critical reading of Scripture that embraces the political nature of Jesus' ministry, and that that does not necessarily entail the non-violent and loving attitude that many white theologians propagate. The "Movement for Black Lives" upholds the value of love, but it also demands more than love. It demands an end to the violence in all its forms perpetrated against black people, 
it demands reparations and investment in black communities, and it demands defunding the institutions and systems that criminalise black people. It demands an alternative society and policies that shift power structures (Movement for Black Lives 2016).

Finally, the black theology of Pinn and others sets the groundwork for churches to centre the body in the work for racial justice. Ministers preaching on the topic need to acknowledge the materiality of the black body and the ways in which racism-both overt and covert, across multiple levels and throughout history-lands, "with great violence, on the body" (Coates 2015, 10). Additionally, ministers need to acknowledge all of the ways in which social structures have shaped and defined the black body over time and the damage these constructions have also done. One cannot separate the concept of racism from the actual people it lands on throughout the life course. Furthermore, following Pinn's recommendation that an embodied problem must be met with an embodied response, churches must consider what an embodied response looks like in their context. In some instances, this will mean putting one's own body on the line in the street in black-led protest.

These are but a few examples of the ways that black theology can help shape the ways that religious denominations respond to the Black Lives Matter movement and to the violence that is perpetrated against the black body. There are thousands of other ways to engage in this response, and ultimately, those ways cannot be prescriptive, but need to be determined in local contexts, in interracial spaces led by black people. The church holds great potential to raise awareness, to provide a space for reconciliation, and to lessen the burden of racist violence-and religious leaders who take Scripture and its message seriously will recognise that to be for a God who is on the side of the oppressed, means to be for Black Lives Matter.

\section{REFERENCES}

Ammerman, Nancy. 1980. "The Civil Rights Movement and the Clergy in a Southern Community." Sociological Analysis 41: 339-350.

Association of American Medical Colleges (AAMC). 2015. "Altering the Course: Black Males in Medicine." Washington DC: Association of American Medical Colleges. http://www.aamc.org/blackmalesinmed (accessed 28 September 2016).

Bey, Marquis. 2015. "She Had a Name That God Didn't Give Her: Thinking the Body through Atheistic Black Radical Feminism." Journal of Feminist Scholarship 9: 1-17.

Brodie, Jessica. 2015. "GC2016 plenary pauses for Black Lives Matter demonstration.” UMC.org. http:// www.umc.org/news-and-media/gc2016-plenary-pauses-for-black-lives-matter-demonstration (accessed 28 September 2016).

Clance, Pauline, and Suzanne Imes. 1978. "The Imposter Phenomenon in High Achieving Women: Dynamics and Therapeutic Intervention." Psychotherapy: Theory, Research and Practice 15: 241247. 
Coates, Ta-Nehisi. 2015. Between the World and Me. New York: Spiegel \& Grau.

Cohen, Pam. 2015. "USCCB approves statement on race relations at spring assembly." National Catholic Reporter. $\quad$ https://www.ncronline.org/blogs/ncr-today/usccb-approves-statement-race-relationsspring-assembly (accessed 28 September 2016).

Cone, James H. 1975. God of the Oppressed. Maryknoll, N.Y.: Orbis Books.

Cone, James H. 2011. The Cross and the Lynching Tree. Maryknoll, N.Y.: Orbis Books.

Cooper, Betsy, Daniel Cox, Rachel Lienesch, and Robert P. Jones. 2015. "Anxiety, Nostalgia, and Mistrust: Findings from the 2015 American Values Survey." Public Religion Research Institute. http://www. prri.org/research/survey-anxiety-nostalgia-and-mistrust-findings-from-the-2015-american-valuessurvey/ (accessed 28 September 2016).

Deville, C., Hwang, W., Burgos, R., Chapman, C. H., Both, S., and Thomas, C. R. Jr. 2015. "Diversity in Graduate Medical Education in the United States by Race, Ethnicity, and Sex, 2012." JAMA Intern Med, 175: 1706-1708.

Elder, Bruce. 2003. Blood on the Wattle: Massacres and maltreatment of Aboriginal Australians since 1788. Australia: New Holland Publishing.

Garza, Alicia. "A HerStory of the \#BlackLivesMatter Movement." Black Lives Matter. http:// blacklivesmatter.com/herstory/ (accessed 27 September 2016).

Geller, Amanda, Jeffrey Fagan, Tom Tyler, and Bruce G. Link. 2014. “Aggressive policing and the mental health of young urban men." American Journal of Public Health 104: 2321-2327.

Geronimus, Arline T., Hicken, M., Keene, D., and Bound, J. 2006. “Weathering' and Age Patterns of Allostatic Load Scores among Blacks and Whites in the United States." American Journal of Public Health 96 (5): 826-833.

Geronimus, Arline T., Margaret T. Hicken, Jay A. Pearson, Sarah J. Seashols, Kelly L. Brown, and Tracey Dawson Cruz. 2010. "Do US Black Women Experience Stress-Related Accelerated Biological Aging? A Novel Theory and First Population-Based Test of Black-White Differences in Telomere Length." Human Nature 21: 19-38.

Green, Emma. 2016. "Black Activism, Unchurched." The Atlantic. March 22, 2016. http://www. theatlantic.com/politics/archive/2016/03/black-activism-baltimore-black-church/474822/ (accessed 28 September 2016).

Hall, Deborah, David C. Matz, and Wendy Wood. 2010. "Why Don't We Practice What We Preach? A MetaAnalytic Review of Religious Racism." Personality and Social Psychology Review 14: 126-139.

Han, B., Compton, W. M., Jones, C. M., and Cai, R. 2015. "Nonmedical Prescription Opioid use and use Disorders among Adults aged 18 through 64 years in the United states, 2003-2013." JAMA 314: $1468-1478$.

Integrate [def 1]. In Cambridge English Dictionary Online. http://dictionary.cambridge.org/dictionary/ english/integrate (accessed 28 September 2016).

Kaiser Family Foundation. "Infant Mortality Rate (Deaths per 1,000 Live Births) by Race/Ethnicity." 2011-2013. The Henry J. Kaiser Family Foundation. http://kff.org/other/state-indicator/infant- 
mortality-rate-by-race-ethnicity/?currentTimeframe $=0 \&$ sortModel $=\% 7 \mathrm{~B} \% 22$ colId $\% 22: \% 22$ Locatio n\%22,\%22sort $\% 22: \% 22$ asc $\% 22 \% 7 \mathrm{D}$ (accessed 28 September 2016).

Krieger, Nancy. 2005. "Embodiment: A Conceptual Glossary for Epidemiology.” J Epidemiol Community Health 59: 350-355.

Krieger, Nancy. 2014. "Discrimination and Health Inequities.” In Social Epidemiology (2nd edition), edited by Lisa F. Berkman, Ichiro Kawachi, and M. Marie Glymour. New York: Oxford University Press.

Lewis, Tené T., Courtney D. Cogburn, and David R. Williams. 2015. "Self-Reported Experiences of Discrimination and Health: Scientific Advances, Ongoing Controversies, and Emerging Issues." Annual Review of Clinical Psychology 11: 407-440.

Lipka, Michael. 2015. “A closer look at Catholic America.” Pew Research Center. http://www.pewresearch. org/fact-tank/2015/09/14/a-closer-look-at-catholic-america/ (accessed 28 September 2016).

Luke 4:18. The Bible: English Standard Version. Wheaton, Ill: Crossway Bibles, 2007.

McArdle, Elaine. 2015. "Board expresses regret for 'enflamed debate' of Black Lives Matter resolution." UU World. http://www.uuworld.org/articles/october-2015-board-meeting (accessed 28 September 2016).

Mofokeng, Takatso. 1983. The Crucified Among the Crossbearers: Towards a Black Christology. Amsterdam: Uitgeversmaatschappij J.H. Kok.

Movement for Black Lives. 2016. "Platform." https://policy.m4bl.org/platform/ (accessed 28 September 2016).

National Center for Health Statistics (NCHS). 2013. "Health, United States, 2013." U.S. Department of Health and Human Services. Hyattsville, MD.

Osborne, Jason W. 2007. “Linking Stereotype Threat and Anxiety.” Educational Psychology 27: 135-154.

Paradies, Y., Ben J., Denson, N., Elias, A., Priest, N., Pieterse, A., et al. 2015. Racism as a Determinant of Health: A Systematic Review and Meta-Analysis. PLoS ONE, 10:9.

Pew Research Center. 2015. "Unitarians and Other Liberal Faiths in 'Other Faiths' Tradition.” Religious Landscape Survey. http://www.pewforum.org/religious-landscape-study/religious-family/unitariansand-other-liberal-faiths-in-the-other-faiths-tradition/ (accessed 28 September 2016).

Pinn, Anthony B. 2010. Embodiment and the New Shape of Black Theological Thought. New York: New York University Press.

Roberts, James Deotis. 1971. Liberation and Reconciliation: A Black Theology. Philadelphia: Westminster Press.

Sampson, Robert J., and William Julius Wilson. 1995. "Toward a Theory of Race, Crime, and Urban Inequality." In Crime and Inequality, edited by J. Hagan, R. D. Peterson and C. A. Stanford. Stanford University Press; 37-54. 
Shreve-Neiger, A. K., and Edelstein, B. 2004. "Religion and Anxiety: A Critical Review of the Literature." Clin Psychol Rev. 24: 379-97.

Singhal, Astha, Yu-Yu Tien, and Renee Y. Hsia. 2016. "Racial-Ethnic Disparities in Opioid Prescriptions at Emergency Department Visits for Conditions Commonly Associated with Prescription Drug Abuse." PLOS ONE 11: 1-14.

Smedley, B. D., Stith, A. Y., and Nelson, A. R. 2003. Unequal Treatment: Confronting Racial and Ethnic Disparities in Health Care. Washington, D.C.: The National Academies Press.

Steele, C., and Aronson, J. 1995. "Stereotype Threat and the Intellectual Test Performance of AfricanAmericans."Journal of Personality and Social Psychology 69: 797-811.

Taylor, J., and Grundy, C. 1996. "Measuring Black internalization of White stereotypes about African Americans: The Nadanolitization Scale." In Handbook of Tests and Measurements for Black Populations (volume 2, pp. 217-226), edited by R. L. Jones. Hampton, VA: Cobb and Henry.

The Guardian. 2016. "The Counted: People killed by police in the U.S.” https://www.theguardian.com/ us-news/ng-interactive/2015/jun/01/the-counted-police-killings-us-database (accessed 28 September 2016).

Thompson, Leonard. 2001. A History of South Africa (3rd edition). New Haven, CT: Yale University Press.

UMC General Council on Finance and Administration. "2014 Membership by Ethnicity and Gender." Statistical Resources, http://www.umc.org/gcfa/data-services-statistics (accessed 28 September 2016).

Unsworth, Tim. 1997. "Racism and religion: partners in crime?" Salt of the Earth. http://salt.claretianpubs. org/issues/racism/unsworth.html (accessed 28 September 2016).

Van Gelder, Sarah. 2015. "Rev. Sekou on Today's Civil Rights Leaders: 'I Take My Orders from 23-yearold Queer Women.'” Yes! Magazine. http://www.yesmagazine.org/peace-justice/black-lives-matter-sfavorite-minister-reverend-sekou-young-queer (accessed 28 September 2016.

Williams, Delores S. 1993. Sisters in the Wilderness: The Challenge of Womanist God-talk. Maryknoll, N.Y.: Orbis Books.

Williams, Shannen Dee. 2015. "The Global Catholic Church and the Radical Possibilities of \#BlackLivesMatter." Journal of Africana Religions 3: 503-515.

Williams, David R., and Chiquita Collins. 2001. "Racial Residential Segregation: A Fundamental Cause of Racial Disparities in Health." Public Health Reports 116: 404-416.

Williams, David R., and Selina A. Mohammed. 2013."Racism and Health I: Pathways and Scientific Evidence.” American Behavioral Scientist 57: 1152-1173.

Williams, David R., Yu, Y., Jackson, J.S., and Anderson, N.B. 1997. "Racial Differences in Physical and Mental Health: Socioeconomic Status, Stress, and Discrimination." Journal of Health Psychology 2: $335-351$.

Yudell, Michael, Dorothy Roberts, Rob DeSalle, and Sarah Tishkoff. 2016. "Taking race out of human genetics." Science 351: 564-565. 